\title{
Art, time and thought: a formal study comparing Palaeolithic and postglacial art
}

\author{
Felipe Criado Boado and Rafael Penedo Romero
}

The formal analysis of art and subjectivities

This paper offers a formal description of Palaeolithic cave art and Levantine postglacial art. It considers its internal characteristics and examines the way in which these may have related to different imaginary universes and to distinct social systems. It builds on the basic premise of structural anthropology that there is a necessary correspondence between all the components of a specific cultural phenomenon. Meaning arises from the network of correspondences within which that particular phenomenon is located.

It is a basic problem of formal analysis in archaeology that we cannot gain access to the ideas which lay behind the features that we are studying. We can only analyse them in the present, and this has given rise to an excessive subjectivity. This is especially true in the case of prehistoric art, which cannot be interpreted without gaining access to the myths and narratives of those who created it.

It is not easy to address this problem, although we have raised the possibility of basing archaeological interpretations on models of subjectivity different from our own (Criado, in press a and c). Such models are based on the work of Lévi-Strauss and employ his notion of the 'savage mind' and the 'domesticated mind' in analysis of the archaeological record (Lévi-Strauss 1962). This has provided a framework for interpreting the origins of megalithic monuments (Criado 1989a) and for the studies of the social and cognitive dimensions of ancient landscapes (Criado, in press b). The present paper takes a similar approach to Palaeolithic and Spanish Levantine art and investigates the conceptions of time and space involved in their creation. It also shows that these art styles reveal distinct strategies for appropriating nature and constructing a social landscape.

This work has important limitations. One follows directly from the strategy of treating both art styles as homogenous entities without attending to the variability present within them. At the same time, although we are attempting to uncover different subjective models in the past, our analysis necessarily involves aesthetic evaluations of a radically contemporary nature.

World Archaeology Volume 25 No. 2 Conceptions of Time and Ancient Society (C) Routledge 1993 0043-8243/93/2502/187 \$3.00/1 


\section{Felipe Criado Boado and Rafael Penedo Romero}

Table 1 The faunal remains from selected Palaeolithic and postglacial sites in south-west France and Spain.

\begin{tabular}{|c|c|c|c|c|c|}
\hline Animals represented & No. & $\%$ & Faunal remains & No. & $\%$ \\
\hline \multicolumn{6}{|l|}{ LASCAUX } \\
\hline Equus ferus & 355 & 60.6 & Rangifer tarandus & 118 & 88.7 \\
\hline Cervus elaphus & 88 & 15 & Capreolus capr. & 6 & 4.5 \\
\hline Bos primigenius & 87 & 14.8 & Sus scrofa & 6 & 4.5 \\
\hline Capra ibex & 35 & 6 & Cervus elaphus & 2 & 1.5 \\
\hline Bison priscus & 20 & 3.4 & Equus ferus & 1 & 0.8 \\
\hline Rangifer tarandus & 1 & 0.2 & & & \\
\hline \multicolumn{6}{|l|}{ EKAIN } \\
\hline Equus ferus & 34 & 57.6 & Cervus elaphus & 47 & 19 \\
\hline Bison priscus & 11 & 18.6 & Capra pyrenaica & 160 & 67 \\
\hline Capra pyrenaica & 5 & 8.5 & Rupicapra rup. & 9 & 3.7 \\
\hline Cervus elaphus & 3 & 5.1 & Bison-Bos & 3 & 1.2 \\
\hline Ursus arctos & 2 & 3.4 & Rangifer tarandus & 4 & 1.6 \\
\hline Rhinoceros? & 2 & 3.4 & Capreolus cap. & 2 & 0.8 \\
\hline \multirow[t]{4}{*}{ Pisces } & 2 & 3.4 & Equus & - & - \\
\hline & & & Ursus spelaeus & 7 & 2.9 \\
\hline & & & Canis lupus & 6 & 2.5 \\
\hline & & & Salmo salar & 1 & 0.4 \\
\hline \multicolumn{6}{|l|}{ TITO BUSTILLO } \\
\hline Equus ferus & 27 & 37.5 & Cervus elaphus & 3120 & 81.2 \\
\hline Cervus elaphus & 23 & 31.9 & Capra pyrenaica & 449 & 11.7 \\
\hline Capra pyrenaica & 9 & 12.5 & Equus ferus & 14 & 3.9 \\
\hline Rangifer tarandus & 7 & 9.7 & Rupicapra rup & 76 & 1.9 \\
\hline Bison priscus & 3 & 4.2 & Bison-Bos & 40 & 1 \\
\hline \multirow[t]{2}{*}{ Bos primigenius } & 3 & 4.2 & Capreolus cap. & 3 & 0.08 \\
\hline & & & Rangifer taran. & 1 & 0.03 \\
\hline \multicolumn{6}{|l|}{ SANTIMAMINE } \\
\hline Bison priscus & 20 & 68.9 & Bison-Bos & - & 22 \\
\hline Equus sp. & 4 & 13.8 & Equus caballus & - & 22 \\
\hline Capra ibex & 3 & 10.3 & Cervus elaphus & - & 18 \\
\hline Ursus sp. & 1 & 3.4 & Capra pyrenaica & - & 15 \\
\hline \multirow{2}{*}{ Cervus elaphus } & 1 & 3.4 & Sus scrofa & - & 9 \\
\hline & & & Capreolus cap. & - & 6 \\
\hline \multicolumn{6}{|l|}{ LA MADELEINE } \\
\hline Equus & - & 43 & Rangifer tarandus & - & 92 \\
\hline Rangifer tarandus & - & 21 & Equus & - & 4 \\
\hline \multicolumn{6}{|l|}{ LA VACHE } \\
\hline Equus & - & 25 & Cabra montes & - & 88 \\
\hline Cabra montes & -- & 18 & Equus & -- & 0 \\
\hline
\end{tabular}


Table 1 Continued.

\begin{tabular}{lcclrl}
\hline Animals represented & No. & $\%$ & Faunal remains & No. & $\%$ \\
\hline REMIGIA Y CINGLE & DE LA GASULLA & LES MALLAETES & & \\
Capridos & - & 39 & Oryctolaqus cunic & 295 & 45 \\
Cervus elaphus & - & 16 & Capra & 234 & 36 \\
Sus scrofa & - & 11 & Cervus elaphus & 94 & 14 \\
Bos & - & 10 & Equus & 7 & 1 \\
Small carnivores & - & 2 & Bos primigenius & 6 & - \\
Cervus capreolus and & & & & 5 & - \\
Equus & - & 1 & Sus scrofa & 3 & - \\
Uncertain & - & 20 & Felis sp. & 3 \\
\hline
\end{tabular}

\section{Palaeolithic versus Levantine art}

There are clear differences between Palaeolithic art and Levantine art. Based on these differences, we can suggest that they belong to different and antagonistic symbolic and social universes.

The basic contrast between both art styles is that while Palaeolithic art does not 'represent' sources that are 'hunted' or herded (Altuna 1983; Castaños 1986; LeroiGourhan 1983: 46-50), the opposite is the case with Levantine art (Estévez 1988; Olaria 1988: 378; Olaria, Estévez and Yill 1982; Olaria and Gusi 1983). As we can see from Table 1 , there are clear examples of this pattern at the Palaeolithic sites of Lascaux and Ekain (Altuna 1983) and, apart from a few examples, at Tito Bustillo (Altuna 1983) and Santamamiñe (see Appellániz, 1982) for the fauna and Altuna (1972) for the art). The same pattern extends to La Madeleine and La Vache (Delporte 1981).

In Levantine art (hereafter abbreviated LA) the animals which appear most frequently are deer, goat (ibex or pyrenaica), bos taurus and sus scrofa. Bulls are the dominant animals in the earliest phases of the art, and horses, dogs, reindeer and insects only rarely occur (Beltrán 1984: 355-6). In general the repertory of animals hunted coincides with those most frequently represented in the art (Olaria and Gusi 1983: 24); Table 1 compares the fauna hunted at Las Mallaetes (Davison 1976) and the art at Cingle de La Gasulla and Cueva Remigia (Viñas Vallverdú and Sarria Boscovich 1978). More specifically, if we take the cave shelters situated less than an hour away from Cova Fosca (Castellón), we find the animals depicted there correspond with the faunal remains found at the excavation (Olaria, Estévez and Yill 1982; Olaria and Gusi 1984; Estévez 1988); in fact they share almost 90 per cent of species in common (Olaria 1988: 377-8).

Thus we can state that in LA what is hunted is also depicted. The opposite is true of Palaeolithic art (hereafter PA). This seems to indicate a difference between the character of the societies in which they appeared. In LA animals which are hunted are also 'good for thinking' or representing, while in PA the choice of animals to be depicted is not identical to the repertory of animals being hunted.

However, in order to pursue these interpretations exhaustively it is necessary to review a series of oppositions between the two art styles. These oppositions are listed in Table 2 and 
Table 2 Major oppositions between Palaeolithic and postglacial arts.

\begin{tabular}{|c|c|c|}
\hline & Palaeolithic art & Postglacial art \\
\hline \multicolumn{3}{|c|}{ SPATIAL LOCATION } \\
\hline 1.11 & Deep inside & Open air \\
\hline 1.21 & Restricted access & General access \\
\hline 1.3 & Settlement $<>$ ART & Settlement $=\mathrm{ART}$ \\
\hline \multicolumn{3}{|c|}{ LIGHT CONDITIONS } \\
\hline 2.11 & Dark & Luminosity \\
\hline 2.27 & Torch light & Natural light \\
\hline \multicolumn{3}{|c|}{ THEMATIC } \\
\hline 3.11 & NO human figures & Human figures \\
\hline 3.21 & NO infrastructural elements & Linked to infrastructural elements \\
\hline 3.3 & Hunting//representation & Hunting $=$ representation \\
\hline 3.41 & NO human activities & Human activities \\
\hline \multicolumn{3}{|c|}{ REPRESENTATION } \\
\hline 4.11 & Naturalistic & Schematic \\
\hline 4.2 & Ecological & Non ecological \\
\hline 4.3 & Motif & Theme \\
\hline 4.4 & Figure & Argument \\
\hline \multicolumn{3}{|c|}{ COMPOSITION } \\
\hline 5.1 & Disorder & Order: long friezes \\
\hline 5.2 & NO given edges & Articulation around one edge \\
\hline 5.3 & Plurality of points of view & Just one point of view \\
\hline 5.4 & 3dimensional & 2-dimensional \\
\hline 5.5 & Use of natural elements & NO use of natural elements \\
\hline 5.6 & NO environmental elements & Environmental elements \\
\hline \multicolumn{3}{|c|}{ PERFORMANCE } \\
\hline 6.1 & Not viewed as a unitary whole & Viewed with a single glance \\
\hline 6.2 & NO narrative & Narrative \\
\hline 6.3 & Not discursive & Discursive \\
\hline 6.4 & Atemporal figuration & Temporal succession \\
\hline 6.5 & Immobility & Filmic character: sequence \\
\hline
\end{tabular}

are illustrated in the figures and tables which accompany this text (a more detailed description can be found in Criado and Penedo 1989: 8-11).

The first group of oppositions refers to the spatial location of each art style. Although PA is found in certain cases outside caves (Beltrán 1987: 16; Laming-Emperaire 1962; Leroi-Gourhan 1965: 447; 1983), it is found in areas where access is difficult (for example Buxu, Montespan or Trois-Frères (Leroi-Gourhan 1965: 447)).

The second group of oppositions is very important and concerns the fact (noted by Giedion 1981) that PA cannot be visually grasped in large panels, while for LA the lighting conditions do permit the visualization of broad compositional groupings. PA can only be discovered through local point-like illumination furnished by the flame of a torch, or the 
beam of light from a lantern (this fact is related to the concept of the 'manual field' (Leroi-Gourhan 1983: 19)).

In the third group the rarity of human representations stands out ( 4.7 per cent of the total number of figures in PA, as compared to 28 per cent in LA (Leroi-Gourhan 1965: 443; Viñas 1977)). Moreover, in PA the human figure is treated in a way which establishes a continuum between the human and animal worlds (Gonzalez and Freeman 1981; 1982; Leroi-Gourhan 1965: 461; Ripoll 1971/2). PA presents us above all with a bestiary; that is, a specific group of animals which are 'used' as objects of representation independently of any economic utility (Leroi-Gourhan 1983: 46).

A fourth group of oppositions refers to different stylistic characteristics. The contrast between the naturalism of PA and the schematism of LA does not exclude the possibility that the latter had an initial naturalistic phase (Beltrán 1982), but it does suggest that PA had a greater capacity to represent nature faithfully; that is, to represent the ecological and ethological reality of the animals concerned (Bandi 1968: 13-19; 1984: 563-71; Mithen 1988). Related to this is the fact that the overall evolution of PA was from schematism to naturalism, while that of LA was from naturalism to schematism (Leroi-Gourhan 1965; 1983; Beltrán 1982; Ripoll 1968: 165--91). Extensive compositions centred on a concrete theme predominate in LA; partly due to the presence of human figures, it is possible to follow a specific visual narrative.

The fifth group of oppositions refers to the compositional form of both art styles. The disposition of specific figures perfectly exemplifies these differences. The fact that there is no privileged point of observation in PA stands out. Each figure in a panel must be seen from its own individual viewpoint; and this often gives rise to the need for a plurality of perspectives, so that a change in the point of view of the observer leads to a change in the interpretation of the artistic representation (see Giedion 1981:574-85). Also, the utilization of natural three-dimensional features of the rock surface differentiates PA from LA which is laid out on an even surface.

The last group of oppositions covers what we might define as performance. By this we refer to the dynamic aspects of theme, style, and composition. The unity of LA is perfectly illustrated by the rockshelter of Plano del Pulido (Eiroa 1985). We should emphasize the narrative and discursive qualities of LA, consistent with its greater 'everyday, mundane' quality, as opposed to PA. These features allow the visual argument in LA to produce an image of temporal succession which is not found in PA. The horizontal ordering of the images in relation to the line of the earth's surface reinforces this impression and signifies that the scene depicted is taking place at a specific time. However, the predominance of individual figuration in $\mathrm{PA}$ and the absence of a narrative or a unified point of view eliminate any possible reference to time. So while LA is a temporal art which demonstrates its mastery through the moulding of specific instants, the preferred mode of action of PA is the expression of space. Although PA possesses a considerable capacity to delineate the movement of individual figures, more generally it is an immobile art which does not reflect group or social dynamics.

We can offer a preliminary interpretation of these differences and suggest that the fundamental contrast expressed through the two art styles is that of a social art (LA) as distinct from an art which is removed from the everyday world (PA).

This implies that the two art forms are immersed in cognitive systems which possess 
totally distinct concepts of space and time and represent the relationship between society and nature in a different way.

\section{Arts and representations}

By reorganizing some of these contrasts, we can emphasize a number of important themes.

\section{Depiction, human beings and society}

First, we shall try to see how human and social activities are depicted in the art. In contrast to LA, the most obvious characteristic of PA is the almost complete absence of human figures and activities within the representation.

PA is more preoccupied with the representation of nature than with signifying the presence of man within nature (Figs 1 and 2). However, LA loses itself within the overall contours of nature and depicts individual entities with less care than PA.

Furthermore, the appearance of a visual narrative in LA accords with this difference (Fig. 3). This does not imply that PA lacks any sense of linear narrative, but it certainly means that the linear narrative does not belong to the explicit order of representation, but to its implicit meaning. On the other hand, in LA the explicit presence of a narrative sequence is a consequence of the appearance of man within the representation. When this is the origin and focus of representation it becomes possible to understand the drama being depicted.

We find ourselves faced with the paradox of an art (PA) apparently distanced from the individual's activities, but which is located in settlement sites (Moure 1987: 30) while LA, intimately related to the human figure and social activities, is found in areas remote from the settlement. This can be resolved if we take into account the fact that LA does in fact appear to be closely related to activity areas. LA was created at sites from which hunters could observe their prey or catch them while on the move (Alonso del Real 1977); it is found in rocky terrain, surrounding areas of good pasture, or along lines of movement, cattle paths and so on.

We can say that PA does not consider human activities or their place in nature. It is concerned exclusively with nature, but it is located within domestic space. However, $L A$ analyses human activities and places them within nature, but it does this from outside domestic space.

Therefore, the contrast between the animals hunted and those represented in the art has its counterpart in their mode of representing human activities. One art (LA) emphasizes the individual, situating his activities within artistic representation and relates them to the natural world. The other art form (PA) shows a general lack of interest in the individual and constructs a representational world which is entirely a world of nature. Also, in contrast to PA, LA 'contemplates culture' and situates culture within nature.

However, PA, which is concerned only with nature, confines this line of thought to the sheltered space of the domestic world. On more detailed inspection it might indeed be said that the space of representation and domestic space do not in fact coincide in PA. While LA is situated in the outermost parts of the cave, PA is withdrawn into its depths 


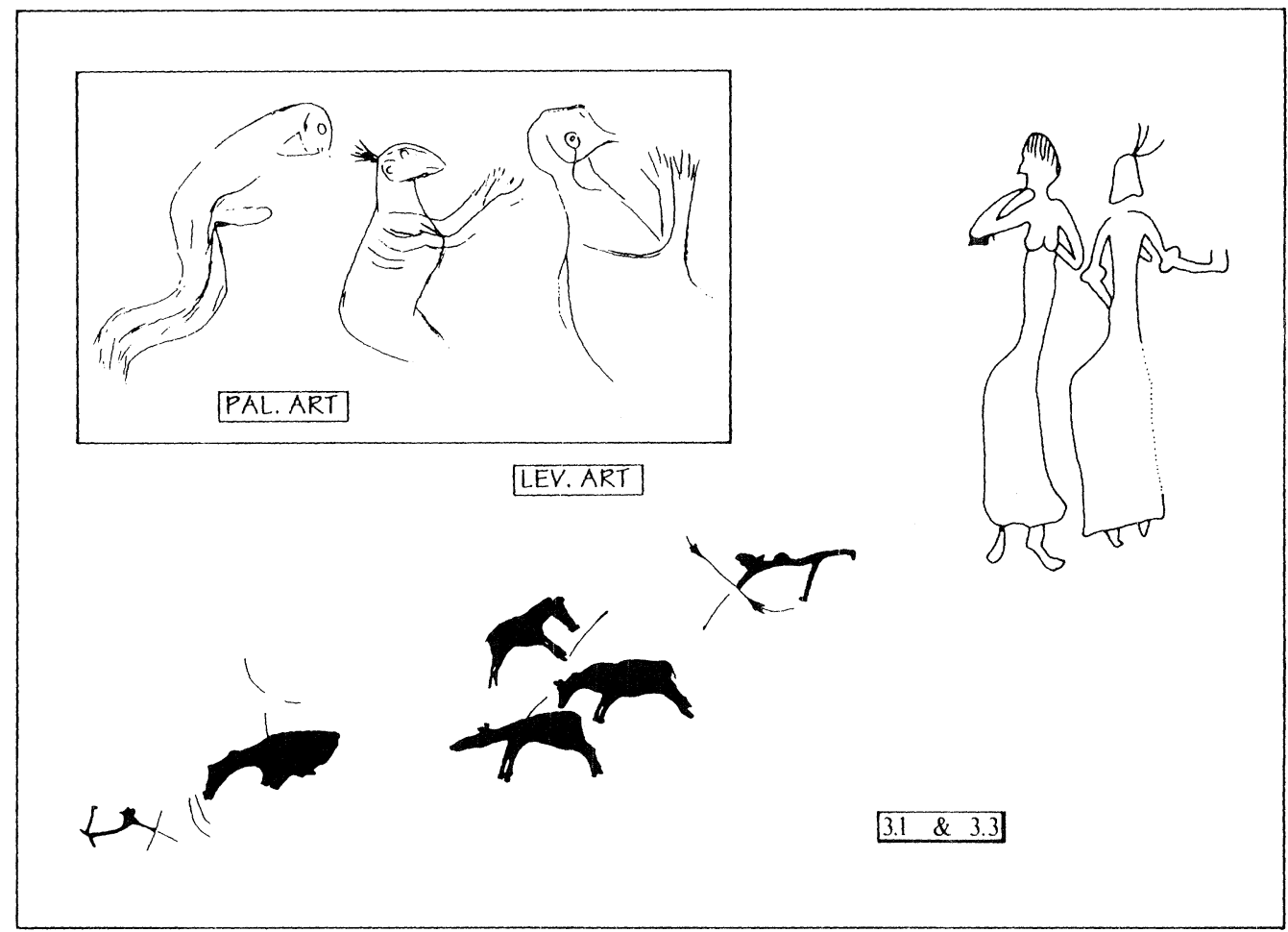

Figure 1 Themes in Palaeolithic and Levantine art. The numbers refer to the comparisons set out in Table 2.
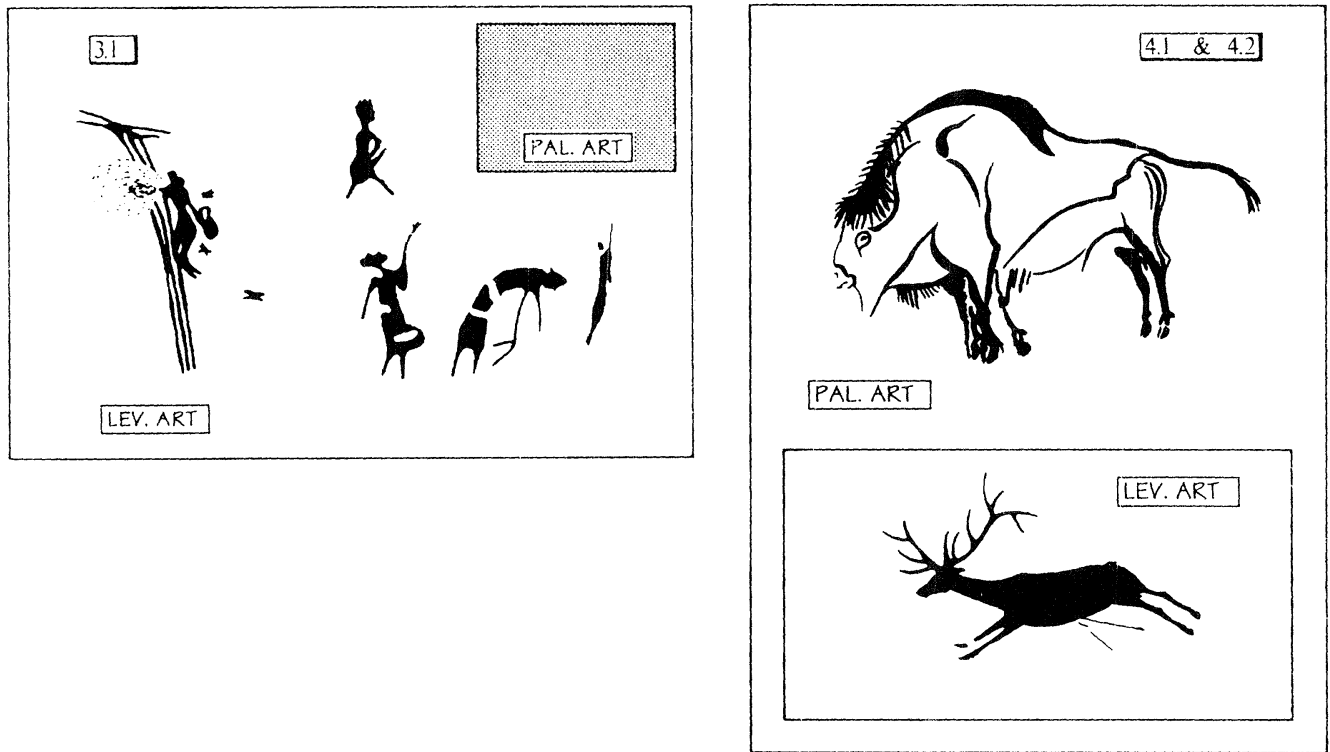

Figure 2 The representation of humans and animals in Palaeolithic and Levantine art. The numbers refer to the comparisons set out in Table 2. 


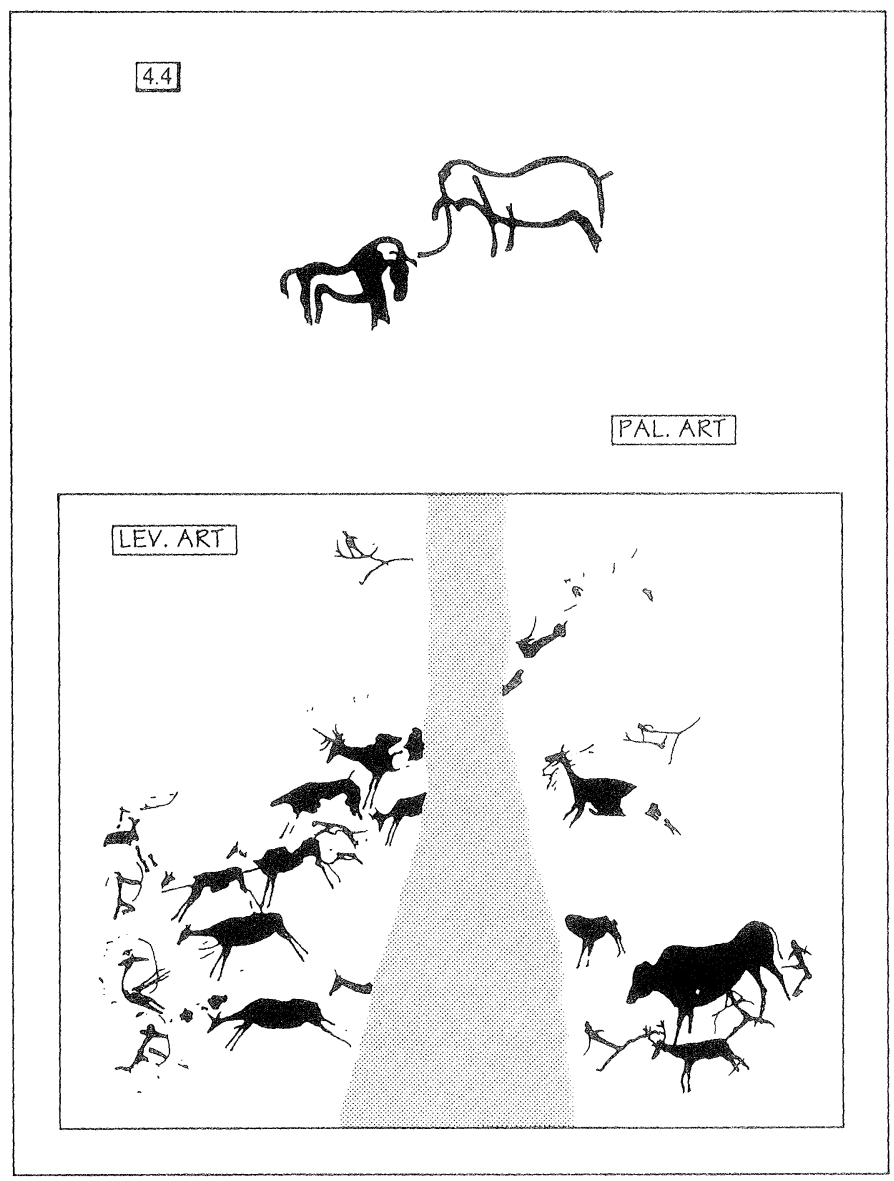

Figure 3 Contrasts in the mode of representation in Palacolithic and Levantine art. The numbers refer to the comparisons set out in Table 2.

(Moure 1987). So this enclosure of artistic discourse within domestic space might better be described as its 'eclipse' within the depths of the cave; within, but at the same time beyond, everyday culture.

Through these observations we can begin to perceive distinct strategies for articulating nature and culture. In order to deepen this interpretation, we must now tackle a second theme.

\section{Representation, space, time}

Every art style has both an 'internal' and an 'external' dimension. That is to say, every representation is, on the one hand, endowed with some kind of intrinsic coherence, while, on the other, it demands a specific orientation from the viewer. Obviously the demands made by the art work are closely related to the configuration of its internal world.

For example, we have seen that LA clearly depicts motion. In order to grasp this movement the spectator must remain immobile. However, PA does not display the generalized movement found in LA, which does not mean that PA does not capture the 
Table 3 Representation of space.

\begin{tabular}{lll}
\hline & Palaeolithic art & Postglacial art \\
\hline Inside & Open space & Closed space \\
& No given edges & Articulation around one edge \\
& Plurality of points of view & Only one point of view \\
& 3-dimensional space & 2-dimensional space \\
& Not viewed as a unitary whole & Vicwed as a unitary whole \\
& Disorder & Order \\
Outside & Order is made by observer & Order is within the representation \\
\hline
\end{tabular}

movement of individual figures. As a consequence it is the viewer who must move, and by so doing create the dynamic of the composition.

Using these categories, we can try to understand the conceptualization of space and time in each art style. The absence of an inherent order in PA permits us to assert that we are dealing with the configuration of an open space (Table 3). There are no predetermined

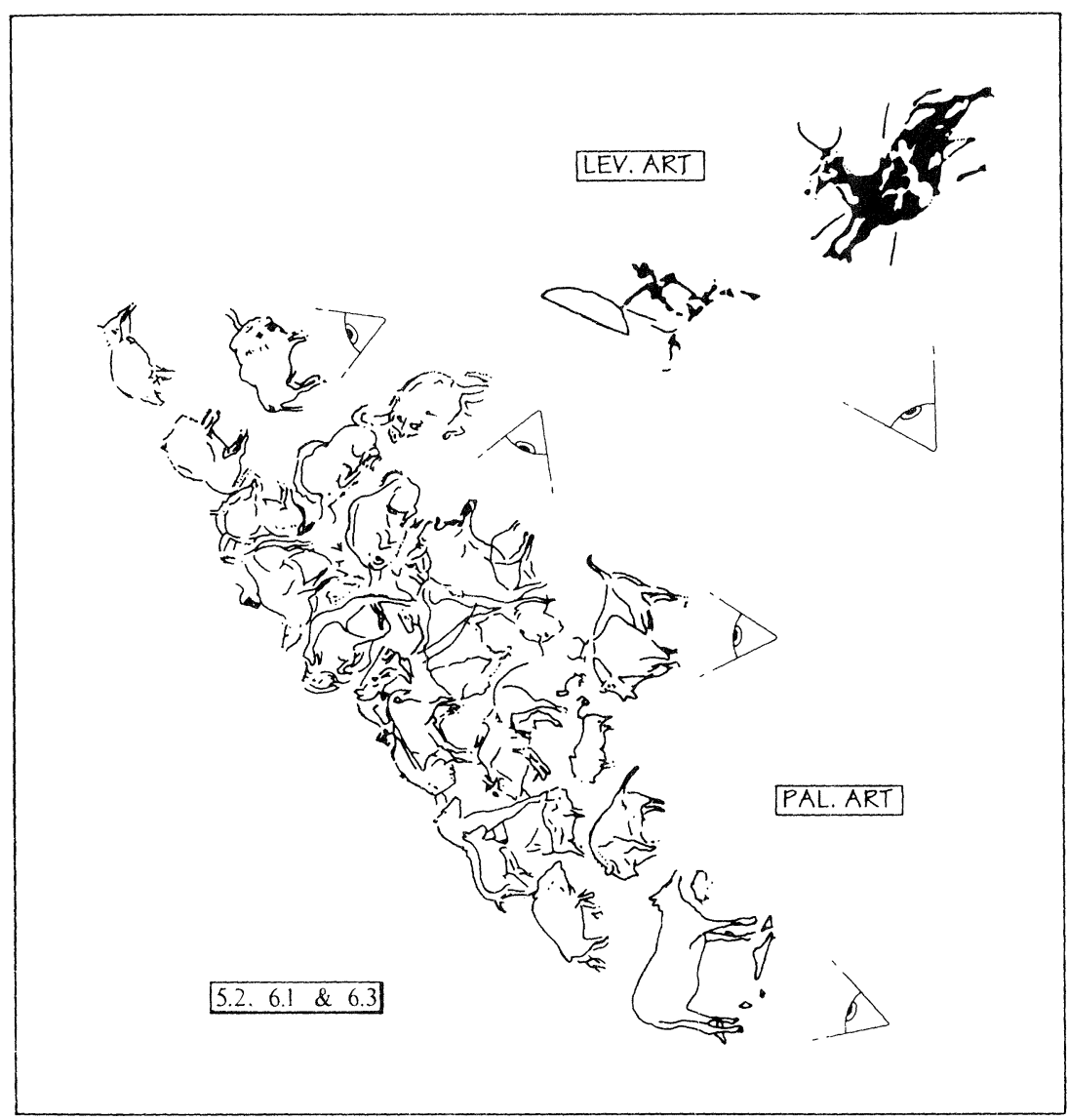

Figure 4 Contrasts in the composition of Palaeolithic and Levantine art. The numbers refer to the comparisons set out in Table 2 . 
axes of vision, but a plurality of points of view (Fig. 4). The figures are three-dimensional and their configuration cannot be grasped in a unitary fashion, with a single glance.

Therefore this disorder is ordered by the viewer, who, through individual interaction with the representation, chooses or describes whatever order he can find in it. In LA we find a space which is closed: one where there is a clear order inherent in the representation. This order is designed to be viewed from a focal point. If we were to look at each figure as an individual form, it would be impossible to understand its role in the total composition.

The consequence of this is that here, unlike PA, the spectator is not expected to impose order on the composition; the correct order is already contained within the composition itself.

Concerning the representation of time (Table 4), let us return to PA. If a spectator creates the spatial form of the art by moving rather than remaining in one place, that representation does not contain a predetermined temporal order. The emphasis on the individual figure and motif underlines this absence. PA is neither narrative nor discursive; its elements are stationary. This indicates that this is an art which is not interested in time. Accordingly, PA leaves the viewer to construct the experience of time himself.

Exactly the opposite occurs in LA. Here the existence of an order internal to the composition implies the existence of a temporal dimension within the artistic representation. Narrative sequence endows the composition with an almost authoritative order/structure. As a consequence, narrative and thematic coherence are emphasized to a degree unknown in PA. In this art form (LA) the experience of time is no longer left to the observer. Instead, it is the observer who is held in a specific position by the need to interpret the temporal unity latent in the artistic composition.

Table 4 Representation of time.

\begin{tabular}{lll}
\hline & Palaeolithic art & Postglacial art \\
\hline Inside & No time (figure and motif) & Time (argument and theme) \\
& No narrative & Narrative \\
& No discursive elements & Discursive \\
& Atemporality & Succession \\
& Inmobility & Sequence \\
Outside & Observer is mobile & Observed is fixed \\
\hline
\end{tabular}

Table 5 Human presence in the art.

\begin{tabular}{ll}
\hline Palaeolithic art & Postglacial art \\
\hline Inside the representation: & Inside the representation: \\
No human interference & Human interference \\
Outside the representation: & Outside the representation: \\
Human interference and & No human interference \\
Participation of the observer & No participation of the observer \\
\hline
\end{tabular}


To sum up (Table 5): in PA we find an equilibrium between the absence of human interference within the art work and its emphatic existence outside that work. The participation of the observer contrasts with the absence of any distinctive role for him within the representation. In LA we find the opposite situation. Here the existence of human interference within the representation is contrasted with its absence outside. The observer does not participate in creating the composition, but human beings do play a part within the representation.

\section{Arts and societies}

If we link the conclusions of the two previous sections, we can begin to understand certain significant features of the two art styles without falling into the simplistic interpretation that $\mathrm{PA}=$ nature and $\mathrm{LA}=$ culture. The observations outlined in Table 6 indicate that space is undefined in PA and that there is no explicit or inherent expression of time. Time and space are the creation of the individual observer interacting with the artistic representation. The representation itself provides material for the individual experience of the observer, an open universe which can support any individual meaning.

However, in LA space is closed and there is an inherent sense of time. The existence of a determinate spatial and temporal network precedes the interaction of observer and representation. The latter constitutes a well-defined 'universe' which predetermines the meanings available to the observer.

We can see that the conceptualizations of space and time specific to each art style are consistent with other features of the two styles. In an art where the observer has a privileged role (PA), it appears quite normal that there are no representations of human beings or activities, and that there is a disjuncture between the fauna hunted and the fauna depicted. In the same way, it is not surprising that such an art, which presents nature 'as it is' without emphasizing the role of the individual, is given to naturalism. For the same reasons, spatial depth and specific environments are not depicted, as they would create a latent order within the representation; something which PA avoids (Fig. 5).

On the other hand, in an art such as LA which subordinates the role of the observing individual, one expects a profusion of human figures and activities and representations of the fauna which are actually hunted. This art is more schematic and is more concerned with moulding a human environment than with faithfully reproducing the forms of specific animals. So, spatial depth and environment are used to create an intelligible visual narrative.

Table 6 Concepts of space and time.

\begin{tabular}{ll}
\hline Palaeolithic art & Postglacial art \\
\hline Space is undefined and time is absent & Closed space and time lies within the space \\
Space and time are made by the observer & Space and time are fixed prior to the observer \\
\hline
\end{tabular}




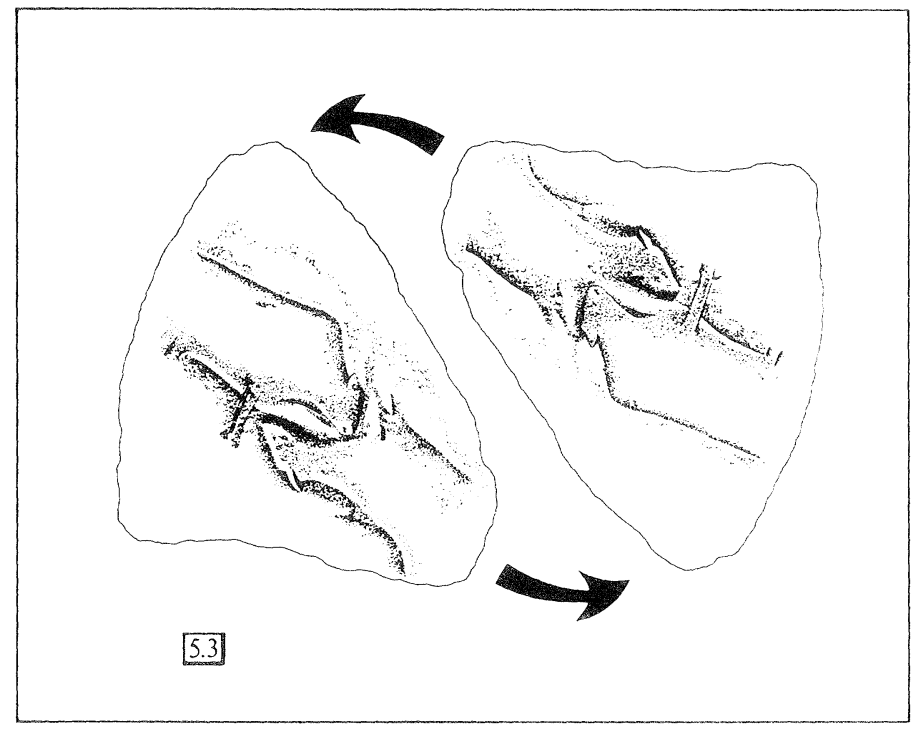

Figure 5 The plurality of viewpoints in Palaeolithic art. The numbers refer to the comparisons set out in Table 2 .

Bringing together these two series of observations, we can conclude that PA is an art without human beings or social influence. Human beings are displaced to the margin of nature; nature is unmoved by human activity, as it possesses a pre-existing and self-sufficient order. In LA, however, it is the appearance of men and women which creates this visual order. Even if the human figure does not actually appear in the representation, the latter has its own temporal order which precedes the observer and is alien to him. For, if society actively imposes an order on nature and art, this implies that the human being as individual observer shall not impose his own order. However, despite the apparent contradiction (active observer $=\mathrm{PA} / /$ passive observer $=\mathrm{LA}$ ), the human being and social group do not lie outside nature in LA; rather, they fulfil their role by organizing their natural environment.

Having arrived at this point, we must note how our interpretation fits in with the socio-economic framework of both art forms (see also Criado and Peuedo 1989: 17-18). In 1966 Jorda argued for a Mesolithic-Neolithic date for LA, and since then various pieces of evidence have suggested that this art style is related to strategies of selective hunting (Olaria 1988: 366-7) and to the early domestication of animals arising from forms of hunting involving closer interaction with the human population (Olaria 1988: 379; 1986a; 1986b; Olaria et al. 1982: 120).

All this suggests that LA, which gives pride of place to the role of the human being in the natural world, is closely linked to an economic context which implies a strong relationship between society and nature. The adoption of selective killing of adult male animals (characteristic of the Mesolithic-Palaeolithic transition, or of early Mesolithic groups (Clark 1975:377)) as opposed to the random hunting of all sexes and age groups (characteristic of Palaeolithic groups), clearly represents this specific attitude towards nature. Mithen (1990) has analysed the economic and social implications of this development. This transformation was not sudden; it had already begun in some Upper Palaeolithic contexts, particularly in the latest phases, where there are clear signs of 
increasingly specialized hunting, possibly even the proto-domestication of horses (Bahn $1978 ; 1980 ; 1981)$.

Behind this change in hunting practices we can observe that the human being is no longer simply an animal which hunts like all other animals, governed by the logic of immediate gain; instead he directs his hunting in a determinate way, selecting his actions and planning them in the medium and long term. The adoption of such a 'conservationist' strategy shows that the human being was seen as an agent capable of interfering destructively in the environment, but also capable of restoring the balance of nature.

This change in hunting strategies should not be understood to imply that Mesolithic groups were more 'ecologically orientated' than Palaeolithic groups, but that there was a change in the conceptualization of human beings in order to preserve the natural order. This changes the 'absolute passivity' of PA into 'active participation' during the Mesolithic, when human beings appear as destructive agents who can, nevertheless, modify their action to restore a suitable state of order.

\section{Art and thought}

From our point of view the close correspondence in each art style between the nature/culture relation and underlying social and economic practices indicates that the transformation from one state to the other involved a corresponding change in thought. In fact, if we consider PA and LA in relation to the three domains we have studied (subsistence practices, the position of human beings in nature, and concepts of space and time), both manage to unite social and symbolic systems which are themselves quite disparate.

PA does not speak of culture, only of nature; it emphasizes human activity and human beings only as a facet of nature, and privileges the individual only in the act of observation. It withdraws the individual from any active role in constructing an image of the world. An art of this type doubtless finds its counterpart in subsistence strategies which develop within the natural order. In these activities people lack any active role; they do not select, plan or rationalize the effects of their actions, nor do they need to maintain the natural order, preventing unnecessary change and assuring the identity of nature and culture. Their activities remain within nature, and their effect is invisible.

The interaction between humans and nature, whether it is expressed through art, economic practices, or their relationship with the environment, remains entirely passive. The logic which dominates the thought of the hunter (which, we believe, is expressed in PA) offers an image of the world which is constructed far from human beings and does not attribute any significance to them. It is for this reason that PA reduces the role of the individual to that of an observer. The system of thought which underlies this art does not permit a human being to order the world. Individuals are limited to the transient living experience of their universe, represented in the darkness and depths of the cave. We could say that the 'logic' of the Palaeolithic hunter is that of a thought which reflects on nature rather than human existence and human culture.

However, we derive a totally opposite impression of LA. Here the human being appears as an actor who can change the environment, although these changes are themselves 
encompassed by a natural order. Rather than destroying this order, human activities serve to sustain it. So, man is not an aggressive agent but lives in harmony with nature, at the heart of an active relation between nature and culture. The social group requires this natural order to reproduce itself, but, rather than depriving human agents of an active role, this requires them to follow specific cultural strategies aimed at supporting this order.

LA speaks of culture, but places it within nature. It denies the role of the observer, as human agency is incorporated within an artistic discourse which emphasizes the compatibility of nature and culture. This type of art finds its counterpoint in hunting practices which emphasize the conservation of a 'correct' natural order and the active role of culture.

The 'logic' which appears to underpin LA is also consistent with ethnographic evidence that hunting can be seen as a form of ecological co-operation rather than destruction. We believe that this logic can be partly reconstructed from Lévi-Strauss' concept of the 'savage mind', which Clastres applied to 'primitive societies' (for an exposition of these concepts see Lévi-Strauss $(1964 ; 1976)$ and Clastres (1981)). In this system of thought the interaction established between nature and culture is one of co-operation. It reflects on nature and culture, gathering them into a unity.

Elsewhere (Criado 1989a; 1989b) we have suggested that the widespread construction of artificial monuments was made possible solely by the destruction of this system of thought and its replacement by a new type of relation between society and nature, along with new concepts of space and time. In general terms it would seem that the mode of thought represented by LA disappeared and a new symbolic system arose in certain areas and in certain social contexts, just as the 'thought' of LA had itself replaced the 'thought' exemplified in PA.

Whether or not one agrees with this framework of three successive systems of thought, we believe that if one compares PA, LA and the monumental landscapes which succeeded them, it is clear that each period witnessed the emergence of new concepts of space and time, and new kinds of relationship between human beings and the environment. The discontinuity between the three phases is so evident that one cannot help but hypothesize that we are dealing with three distinct cognitive systems.

During the Palaeolithic, as represented in PA, the interaction between culture and environment was passive; thought embraced nature and nothing more. During the second period, Mesolithic and Proto-Neolithic, this interaction was active and positive. Thought spoke of nature and culture and established a close collaborative relationship between the two. In the last phase, the Late Neolithic and protohistoric, this interaction was one of human mastery of the environment. Thought fixed on culture, and the mastery of culture over nature. Finally, nature disappeared as an independent force. The environment reappeared as scenery, and the landscape as land (Ingold 1986: ch. 6; Bradley 1993: ch. 1).

\section{Acknowledgements}

The authors sincerely thank the following people: Grant Chambers, for translating the Spanish version, Richard Bradley for encouraging us to produce this text, and Serafín 
Moralejo, whose teaching influenced this work in a way difficult to define but very real. Drawings were made by Anxo Rodriguez Paz.

15.xii.93

Department of History

University of Santiago de Compostela

\section{References}

Alonso del Real y Ramos, C. 1977. Nueva Sociologia de la Prehistoria. Santiago de Compostela: Edic. Pico Sacro.

Altuna, J. 1972. Fauna de mamíferos de los yacimientos prehistóricos de Guipuzcoa. Con catálogo de los mamíferos cuaternarios del Cantábrico y del Pirineo Occidental. Munibe, 24: 1-464.

Altuna, J. 1983. On the relationship between archaeofaunas and parietal art in the caves of the Cantabrian region. In Animal and Archaeology: 1. Hunters and their Prey (eds J. Clutton-Brock and C. Grigson). Oxford: British Archaeological Reports, International Series 163, pp. 227-38.

Appellániz, J. M. 1982. El arte prehistórico del PaIs Vasco y sus vecinos. Bilbao: Ed. Desclee de Brower.

Bahn, P. 1978. The 'unacceptable face' of the West European Upper Palaeolithic. Antiquity, 52: $183-92$.

Bahn, P. 1980. Crib-biting: tethered horses in the Palaeolithic. World Archaeology, 12: 212-17.

Bahn, P. 1981. La néolithisation dans les Pyrénées-atlantiques et centrales. Colloque Néolithique Ancien. Montpellier: CNRS, pp. 191-9.

Bandi, H. G. 1968. Art quaternaire et zoologie. Simposio Internacionale de Arte Rupestre (ed. E. Ripoll). Barcelona: VISPP, pp. 13-19.

Bandi, H. G. 1984. Contribution de la zoologie et de l'ethnologie à l'interprétation de l'art des peuples chasseurs préhistorique. L'Anthropologie, 88: 563-71.

Beltrán Martinez, I. 1982. De cazadores a pastores. El arte rupestre del Levante Español. Madrid: Ed Encuentro.

Beltrán Martinez, I. 1984. Les animaux de l'art rupestre des chasseurs de Levant Espagnol. In La Contribution de la zoologie et de l'ethnologie à l'interprétation de l'art des peuples chasseurs préhistoriques (eds H. G. Bandi et al.). Fribourg: Fribourg Ed. Universitaires, pp. 353-69.

Beltrán Martinez, I. 1987. Arte rupestre prehistórico: crísis de los sistemas tradicionales. In Arte Rupestre en España. Madrid: Revista de Arqueología, pp. 16-18.

Bradley, R. 1993. Altering the Earth. The Origins of Monuments in Britain and Continental Europe. Edinburgh: Society of Antiquaries of Scotland.

Breuil, E. and Obermaier, H. 1984. La Cueva de Altamira en Santillana del Mar. Madrid: Ediciones el Viso.

Castaños, A. 1986. Aspectos ecológicos del arte parietal Paleolítico en Cantabria. In Estudios de Arte Paleolítico. Monograf ías del Centro de Investigacion y Museo de Altamira, 15. Madrid: Ministerio de Cultura, pp. 7-66.

Clark, G. A. 1975. El hombre y su ambiente a comienzos del Holoceno en la región cantábrica. Los cazadores-recolectores asturienses. Boletin del Instituto de Estudios Asturianos, 84-5: 363-87.

Clastres, P. 1981. Investigaciones en antropología política. Barcelona: Gedisa, Paris, 1980.

Criado Boado, F. 1989a. We, the post-megalithic people. In The Meaning of Things. Material Culture and Symbolic Expression. (ed. I. Hodder). London: Unwin Hyman, pp. 79-89. 
Criado Boado, F. 1989b. Megalitos, espacio, pensamiento. Trabajos de Prehistoria, 45: 75-98.

Criado Boado, F. In press. a. The visibility of material culture and the interpretation of social reality. In Interpretative Archaeologies (eds I. Hodder and M. Shanks).

Criado Boado, F. In press. b. Mind and landscape: from rockshelters to monuments and hill-forts. In Social Life and Social Change: the Neolithic of North Western Europe (eds M. Edmonds and C. Richards).

Criado Boado, F. In press. c. La subjetividad extraviada. Sobre arqueología e interpretacion. Trabajos de Prehistoria, 50.

Criado Boado, F. and Penedo Romero, R. 1989. Arte de cazadores y arte de salvajes: una contraposición entre el arte paleolítico y el arte post-glacier levantino. Munibe, 41:3-22.

Davison, I. 1976. Les Mallaetes and Monduver: the economy of a human group in prehistoric Spain. In Problems in Economic and Social Archaeology (eds G. de Sieveking, I. H. Longworth and K. E. Wilson). London: Duckworth, pp. 483-99.

Delporte, H. 1981. L'Object d'art préhistorique. Paris: Ed. de la Reunion des Musées Nationaux.

Eiroa, J. J. 1985. El Plano del Pulido: un abrigo con pinturas de estilo levantino en Caspe (Zaragoza). Ars Praehistorica, 3/4: 261-9.

Estévez, J. 1980. Paleoeconomía y arte prehistórico. In Altamira Symposium, pp. 197-205. Madrid: Ministerio de Cultura.

Garcia del Toro, J. R. 1986-87. La danza femenina de La Risca (Moratalla, Murcia). Bajo Aragon. Prehistoria, VII-VIII: 123-9.

Giedion, S. 1981. El presente eterno: los comienzos del arte. Una aportación al tema de la constancia y el cambio. Madrid: Alianza Ed.

González Echegaray, J. and Freeman, L. G. 1981. La máscara del santuario de la Cueva del Juyo. In Altamira Symposium. Madrid: Ministerio de Cultura, pp. 1-63.

González Echegaray, J. and Freeman, L. G. 1982. La máscara y el santuario del Juyo. Revista de Arqueología, 23: 16-25.

Ingold, T. 1986. The Appropriation of Nature. Essays on Human Ecology and Social Relations. Manchester: Manchester University Press.

Jorda Cerda, F. 1966. Notas para una revisión de la cronología del arte rupestre Levantino. Zephyrus, XVII, 46-76.

Laming-Emperaire, A. 1962. La Signification de l'art rupestre paleolithique. Paris: Ed A. and J. Picard and Cia.

Leroi-Gourhan, A. 1965. Préhistoire de l'Art Occidental. Paris: Ed. de l'Art Lucien Mazenod.

Leroi-Gourhan, A. 1983. Los primeros artistas de Europa. Introducción al arte parietal paleolitico. Madrid: Encuentro Ediciones. Milano, 1980.

Lévi-Strauss, C. 1964. El pensamiento salvaje. Mexico: Fondo de Cultura económica. Paris, 1962.

Lévi-Strauss, C. 1976. El Hombre Desnudo. Mexico. Ed. Siglo XVI. Paris, 1971.

Mithen, S. 1988. Looking and learning: Upper Palaeolithic art and information gathering. World Archaeology, 19: 297-327.

Mithen, S. 1990. Thoughtful Foragers. A Study of Prehistoric Decision Making. Cambridge: Cambridge University Press.

Moure Romanillo, A. 1987. Introducción al arte rupestre paleolítico cantábrico, In Arte Rupestre en España. Madrid: Revista de Arqueología, pp. 30-7.

Olaria, C. 1986a. La problemática del Neolitico Andaluz y sus conexiones con el litoral mediterraneo peninsular. In Homenaje a Luis Siret. Sevilla: Consejeria de Cultura, pp. 130-4. 
Olaria, C. 1986b. Nuevas aportaciones para el conocimiento del Neolítico Antiguo de la costa mediterranea española. World Archaeological Congress, Southampton, 1986. Unpublished.

Olaria, C. 1988. Cova Fosca. Un asentamiento meso-neolitico de cazadores y pastores en la serrania del Alto Maestrazgo (dir. C. Olaria). Diputación de Castellón: Servicio de Arqueología, pp. 281-337.

Olaria, C. and Gusi, F. 1983. Cova Fosca, un asentamiento de cazadores y pastores en la serranía del Maestrazgo. Revista de Arqueología, 27: 18-24.

Olaria, C. and Gusi, F. 1984. Estudio del territorio para la comprensión del hábitat prehistórico: un ejemplo del Neolítico Antiguo. Arqueología Espacial, 3: 41-51.

Olaria, C., Estévez Escalera, J. and Yll, R. 1982. Domesticación y paleoambiente de la Cova Fosca (Castellón). Actes du Colloque International de Préhistoire, Le Neolitique Ancien Mediterranéen: Archeologie en Languedoc, número especial. Montpellier, pp. 107-20.

Ripoll Perelló, E. 1971/2. Una figura de 'hombre bisonte' de la cueva del Castillo. Ampurias, 33-4: 93-110.

Viñas Vallverdu, R. 1977. El Abrigo V de la Serra de la Pictat (Uldecona), Tarragona. Cuadernos de Prehistoria y Arqueología Castellonense, 4: 21-44.

Viñas Vallverdú, R. and Sarria Boscovich, E. 1978. Las representaciones faunísticas del término de Ares del Maestre (Castellón de la Plana). Cuadernos de Prehistoria y Arqueología Castellonense, 5: 146-61.

\section{Abstract}

Criado Boado, F. and Penedo Romero, R.

\section{Art, time and thought: a formal study comparing Palaeolithic and postglacial art}

This paper considers a number of contrasts between Palaeolithic art and Levantine postglacial art and suggests that these are the expression of different conceptions of time and space. They can be related to the socio-economic context in which the art was created. Each style of painting embodies a distinctive approach to time, the natural world and the exploitation of the landscape. 